\title{
Investigation of intestine function during acute viral hepatitis using combined sugar oral loads
}

\author{
G PARRILLI, R CUOMO, G NARDONE, G MAIO, C M IZZO, \\ AND G BUDILLON
}

From the Sezione Autonoma di Epatologia, 2nd Medical Faculty of Naples, and Ospedale Cotugno, USL 41 Naples, Italy.

SUMmary One fifth of all cases of A virus hepatitis (AVH) have symptoms of gastroenteritis at the onset. This study investigated the mediated intestinal absorption of D-xylose (D-xyl) and 3-o-methyl-D-glucose (3-omG) and the non-mediated permeation of lactulose (Lacl, mol wt 342) and L-rhamnose (L-rh, mol wt 164) during acute and remission phases of AVH. Ten patients with $\mathrm{AVH}$ were given an oral load containing these sugars $(5 \mathrm{~g} \mathrm{D}$-xyl: $2.5 \mathrm{~g}$ 3-omG, $1 \mathrm{~g} \mathrm{~L}$-rh, $5 \mathrm{~g}$ lacl in $250 \mathrm{ml}$ water) once during the acute phase and again during remission. The same load was given once to a group of 22 healthy controls. The mean concentration of D-xyl in urine and the ratio of D-xyl to 3-omG in plasma and urine were normal in both the AVH phases, ruling out intestinal malabsorption even in the acute phase. This study showed a significant increase in non-mediated permeation to Lacl, but not to L-rh, during the acute phase. These data indicate that the barrier function of the intestine is compromised in AVH infection while the absorptive function is not. An abnormally low concentration of D-xyl and 3-omG in plasma at one hour was found in all patients during the acute phase. This finding cannot be explained by alterations in intestinal absorption, but could be accounted for by increased space distribution of the sugars because of increased diffusion into tissue cells and/or expansion of the extracellular space by fluid retention.

A-virus hepatitis (AVH) is associated with gastroenteritis symptoms in approximately one of five cases.' Recent reports have suggested direct replication of the A hepatitis virus in intestinal cells, ${ }^{2}$ which could result in altered intestinal function. An acquired monosaccharide malabsorption is often observed in the course of viral gastroenteritis ${ }^{3}$ and can persist after disease regression. ${ }^{+}$Early studies of intestinal absorption during viral hepatitis have given inconsistent data. ${ }^{5}$ In these studies urinary excretion of D-xylose after oral load was used as a measure of active absorption of monosaccharides. Modifications to this test have recently been proposed to correct interference by variables such as distribution space, gastric emptying, and renal clearance. One of these modifications is the determination of the D-xylose (D-xyl) plasma concentration peak at one hour

\footnotetext{
Address for correspondence: G Budillon, MD, Universita` di Napoli, II Facolta di Medicina e Chirurgia, Sezione Autonoma di Epatologia, Via S Pansini 5. 80131 Napoli. Italy.

Reccived for publication 15 April 1987
}

corrected by body surface area (Haeney's method). ${ }^{\circ}$ Another modification is the addition to D-xyl of a second absorption marker, 3-o-methyl-D-glucose (3-omG) which is completely excreted in the urine unmetabolised ${ }^{7}$ and whose absorption is much less hindered by intestinal disease than is that of D-xyl. ${ }^{7}$ This modification allows the correction of plasma and/or urine xylose concentrations by calculating the ratio of D-xyl to 3-omG (Menzies' method). ${ }^{84}$ Because little is known about intestinal dysfunction during viral hepatitis, we designed a sugar absorption study using these new procedures, in patients with AVH.

The measurement of passive intestinal permeability has been recognised recently as a more sensitive tool to explore the functional integrity of the gut. ${ }^{11-13}$ To include this new evaluation we have used a multiple sugar oral load $^{y+14}$ consisting of D-xyl, 3-omG, lactulose (Lacl) and L-rhamnose (L-rh). This test allows simultaneous evaluation of mediated absorption (D-xyl and 3-omG), and non-mediated 
permeation to small molecules (L-rh, mol wt 164), which are passively absorbed through cell aqueous pores $^{15}$ as well as to disaccharide molecules ( $\mathrm{Lacl}$, mol wt 342), whose permeation is thought to be through larger channels related to the tight junctions and/or cell extrusion zones..$^{15}$

An increase in non-mediated intestinal permeation to lactulose was recognised in the acute phase of $\mathrm{AVH}$, while the mediated absorption appeared to be unaffected.

\section{Methods}

PATIENTS AND SUBJECTS

Twenty-two healthy subjects and 10 patients with AVH participated as volunteers after giving informed consent. Hepatitis was diagnosed by typical clinical features, raised transaminase values and the presence of antivirus A IgM. After overnight fast, each subject was given an oral load consisting of $5 \mathrm{~g}$ D-xyl, $2.5 \mathrm{~g} \mathrm{3-omG,} 1 \mathrm{~g} \mathrm{~L}$-rh and $5 \mathrm{~g} \mathrm{Lacl}$ in $250 \mathrm{ml}$ water. Hepatitis patients received this load on two occasions: early the first morning after admission to hospital (within a week of hepatitis symptom onset) and another 30 days after (regression phase). No subject showed intolerance to the load; the osmolarity of the test solution was kept below the level known to induce an alteration in intestinal permeability or motility $(340 \mathrm{mOsm} / \mathrm{l})$. Heparinised blood was obtained before and 30, 60, 90, and 120 minutes after oral load, and plasma samples were stored at $-20^{\circ} \mathrm{C}$. A complete five hour urine collection was made after the oral load and an aliquot of each urine collection was preserved with merthiolate $(10 \mathrm{mg} / 100 \mathrm{ml})$, and frozen. Monosaccharides in plasma and urine were estimated by quantitative thin layer chromatography according to Menzies. ${ }^{16}$ Sugar separation was achieved by multiple development on half plates $(10 \mathrm{~cm} \times 20 \mathrm{~cm})$ of $F 1500$ plastic backed silica gel (Schleicher and Schull, Dassel FRG), using for sugars in the plasma (D-xyl, 3-omG) three consecutive ascending runs $(8.5 \mathrm{~cm}$ each), one with solution A (Butan-l-o/ethan-l-o/acetic acid/ water; 60:50:10:10) and two with solution B (Butan-lo/ethyl-acetate/pyridine/acetic-acid/water: 5:70:15: $10: 10)$. For sugars in the urine (D-xyl, 3-omG, L-rh) three consecutive ascending runs $(8.5 \mathrm{~cm}$ each) were made with solution $B$. The precision of both methods was $7 \%$, recovery above $90 \%$ and minimum level of detection below $0.1 \mathrm{mmol} / \mathrm{l}$ for the three sugars tested.

Lactulose was estimated in urine by gas liquid chromatography according to Laker's method ${ }^{17}$ with modification in the gas-carrier and in its flow rate. The chromatograph was a Fractovap 4002 from Carlo Erba (Italy). The operative conditions were: oven $250^{\circ} \mathrm{C}$, injector $275^{\circ} \mathrm{C}$, detector (ionisation flame) $305^{\circ} \mathrm{C}$, gas-carrier $\left(\mathrm{N}_{2}\right)$, flow $35 \mathrm{ml} / \mathrm{min}$, attenuation input $1: 100$ and output 1:2, back-off 1:100. The column was a 3-metre OV $17(8 \%$ phases of gaschrom Q 80-100 mesh). The lactulose retention time relative to that of turanose (internal marker $10 \mathrm{mg} /$ $100 \mathrm{ml}$ ) was $0 \cdot 73$. The variation coefficient was above $8 \%$ and the minimum concentration value of lacl in urine was $80 \mu \mathrm{g} / 100 \mathrm{ml}$. Values representing timed D-xyl and 3-omG concentrations in plasma for each test were processed (Sperry Univac personal computer) calculating second to tenth degree equations with their integrals. The fourth degree equation, according to correlation coefficients, most accurately expressed the kinetics of the two sugars in plasma. This was used to calculate the area under the 0-120 min plasma curves (PCTA) for each patient and control subject. The values for each group were statistically analysed according to the Student's $t$ and Wilcoxon's tests. Patient biochemical data and sugar parameters were compared according to Pearson's correlation coefficient.

\section{Results}

Table 1 shows biochemical data of the hepatitis patients. All were icteric at the onset of the disease; bilirubin and transaminase values had returned to control levels at the end of the thirty day study period. Renal function was normal in patients and controls, as proven by creatininaemia and urine data. All patients were untreated throughout the observation period. Figure 1 shows the mean plasma levels of D-xyl and 3-omG at different times after oral load.

Figure 2 reports plasma concentrations of $D$-xyl and 3-omG at one hour in each patient and control. The concentrations of both sugars were lower than normal in the acute phase of hepatitis and had returned to normal 30 days later.

Table 2 shows the mean one hour xylosaemia corrected according to Haeney, the mean plasma concentration/time area (PCTA) of D-xyl and

Table 1 Laboratory data of patients with type A hepatitis $(A V H)$ in acute and remission phases (mean values $\pm S D$ ). The measure units and normal range are reported in brackets

\begin{tabular}{|c|c|c|c|}
\hline & Biochemical Data & $\begin{array}{l}\text { Acute } \\
\text { phase }\end{array}$ & $\begin{array}{l}\text { Remission } \\
\text { phase }\end{array}$ \\
\hline & AST (0-40 UI) & $1539 \pm 442$ & $35 \cdot 4 \pm 9 \cdot 3$ \\
\hline & $\operatorname{ALT}(0-40 \mathrm{UI})$ & $2472 \pm 884$ & $47 \cdot 8 \pm 10 \cdot 7$ \\
\hline $\operatorname{AVH}(10)$ & Bilirubin & & \\
\hline \multirow[t]{5}{*}{$\operatorname{AGE}(17-23)$} & Tot $(0 \cdot 2-1 \mathrm{mg} / \mathrm{dl})$ & $9 \cdot 1 \pm 1 \cdot 7$ & $0 \cdot 8 \pm 0 \cdot 3$ \\
\hline & Quick $(70-100 \%)$ & $86 \cdot 8 \pm 9 \cdot 9$ & \\
\hline & Glucose $(60-120 \mathrm{mg} / \mathrm{dl})$ & $78 \cdot 8 \pm 9 \cdot 2$ & \\
\hline & Creatininaemia & & \\
\hline & (0.7-1.5 mg-dl) & $0.72 \pm(0 \cdot 04$ & \\
\hline
\end{tabular}



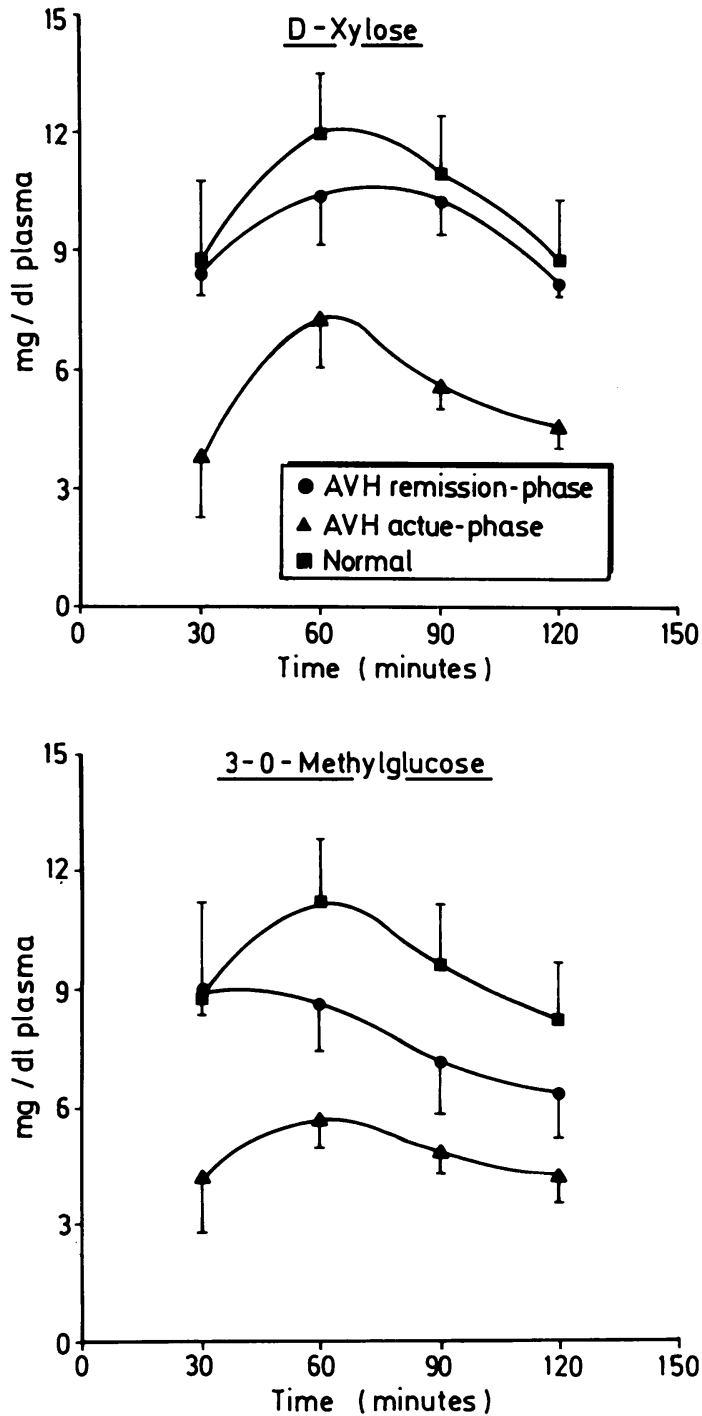

Fig. 1 Plasma values (mean $\pm S D$ ) of D-xylose and 3-o-methyl-glucose in 22 normal subjects and in 10 patients with $A$ viral hepatitis $(A V H)$, in the acute phase of disease and 30 days after.

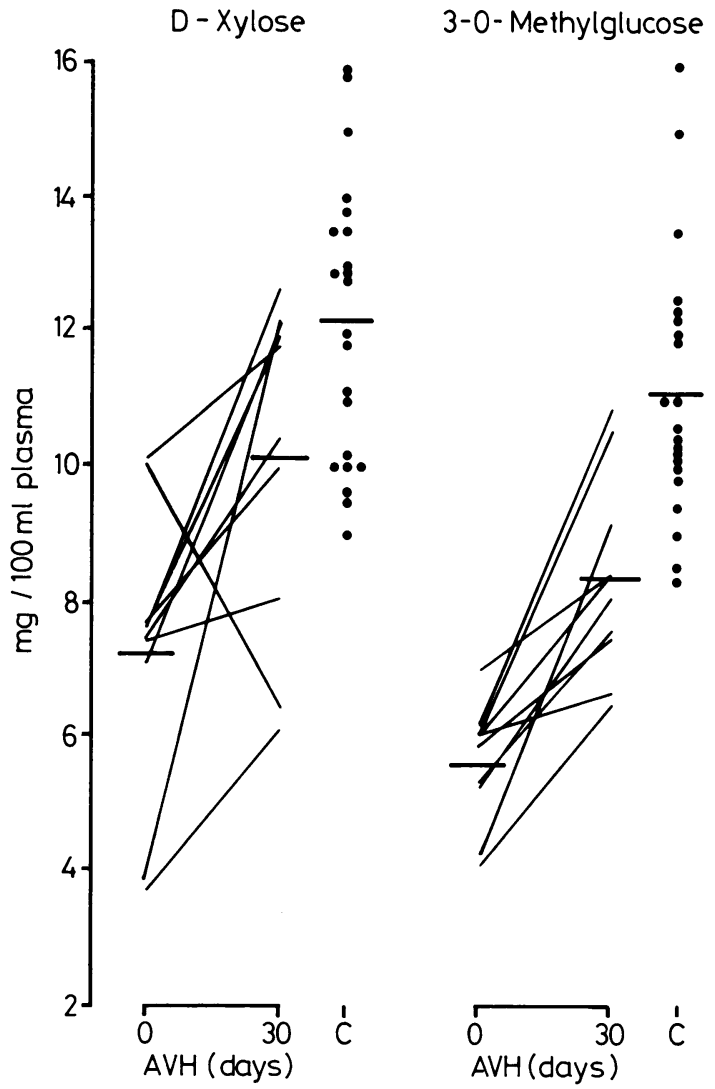

Fig. 2 One hour plasma concentrations of $D$-xylose (D-xyl) and 3-o-methyl-glucose (3-om $G$ ) in acute phase $(0)$ and 30 days after (30) in patients with acute viral hepatitis and in controls $(C)$, with mean values.

3-omG, and the mean plasma ratio of D-xyl to 3-omG. Only the $\mathrm{D}$-xyl/3-omG ratio shows no significant variation among acute and remission phases of AVH and controls.

Table 3 shows per cent recovery of the different sugars in urine, and the $\mathrm{D}$-xyl/3-omG and $\mathrm{Lacl} / \mathrm{L}$-rh ratios. The excretion of D-xyl and 3-omG was similar in patients during both $\mathrm{AVH}$ phases and in controls

Table 2 Plasma parameters of sugars after combined oral loads

\begin{tabular}{|c|c|c|c|c|c|c|}
\hline & \multirow[b]{2}{*}{ Controls (C) } & \multicolumn{2}{|l|}{$A V H$} & \multicolumn{3}{|l|}{$p$} \\
\hline & & $\operatorname{Basal}(A)$ & 30 days $(B)$ & $C \vee A \ddagger$ & $C \vee B \ddagger$ & $A \vee B \$$ \\
\hline $\mathrm{D}-\mathrm{xyl} \mathbf{l}^{*}+$ & $0 \cdot 77 \pm 0 \cdot 10$ & $0 \cdot 49 \pm 0 \cdot 15$ & $0.72 \pm 0 \cdot 13$ & $<0 \cdot 001$ & ns & $<0 \cdot(00) 1$ \\
\hline D-xyl/3omG & $0 \cdot 85 \pm 0 \cdot 18$ & $0 \cdot 96 \pm 0 \cdot 18$ & $0.92 \pm 0.17$ & ns & $\mathrm{ns}$ & ns \\
\hline PCTA D-xyl & $1119 \pm 219$ & $559 \pm 144$ & $1047 \pm 79$ & $<0.001$ & ns & $<0 \cdot(001$ \\
\hline PCTA 3omG & $1037 \pm 203$ & $530 \pm 93$ & $971 \pm 93$ & $<0.001$ & $\mathrm{~ns}$ & $<0 \cdot(001$ \\
\hline
\end{tabular}

${ }^{*}$ Haney’s correction; † mmol/l; $\ddagger$ Wilcoxon’s test $; § S t u d e n t ` s ~ t$ test PCTA= plasmatic concentration/time curve $\left(\mathrm{mg} \times \mathrm{min}^{-1}\right)$. 
Table 3 Urine excretion after combined sugar loads

\begin{tabular}{|c|c|c|c|c|c|c|}
\hline & \multicolumn{6}{|c|}{ Five hour urine excretion (\% oral dose) } \\
\hline & \multirow[b]{2}{*}{ Controls (C) } & \multicolumn{2}{|l|}{$A V H$} & \multicolumn{3}{|l|}{$p$} \\
\hline & & $\operatorname{Basal}(A)$ & 30 days $(B)$ & $C \vee A^{*}$ & $C \vee B^{*}$ & $A \vee B^{+}$ \\
\hline D-xyl & $34 \cdot 0 \pm 6 \cdot 3$ & $31 \cdot 1 \pm 9 \cdot 5$ & $29 \cdot 7 \pm 3 \cdot 9$ & $\mathrm{~ns}$ & ns & $\mathrm{ns}$ \\
\hline 3omG & $56 \cdot 2 \pm 6 \cdot 5$ & $55 \cdot 7 \pm 16 \cdot 4$ & $56 \cdot 0 \pm 5 \cdot 4$ & ns & ns & $\mathrm{ns}$ \\
\hline D-xyl/3omG & $0.61 \pm 0.09$ & $0.55 \pm 0.05$ & $0.52 \pm 0.02$ & ns & ns & ns \\
\hline $\mathrm{L}-\mathrm{Rh}$ & $10 \cdot 2 \pm 3 \cdot 0$ & $10 \cdot 7 \pm 4 \cdot 25$ & $9 \cdot 30 \pm 0 \cdot 5$ & ns & ns & $\mathrm{ns}$ \\
\hline Lacl & $0 \cdot 24 \pm 0 \cdot 1$ & $0.76 \pm 0.29$ & $0 \cdot 39 \pm 0 \cdot 16$ & $<0 \cdot(001$ & $<0 \cdot 05$ & $<0 \cdot(05$ \\
\hline Lacl/L-Rh & $0 \cdot 023 \pm 0 \cdot 01$ & $0 \cdot 076 \pm 0 \cdot 036$ & $0 \cdot 04 \pm 0 \cdot 02$ & $<0 \cdot 001$ & $<0 \cdot 001$ & $<() \cdot() 1$ \\
\hline
\end{tabular}

${ }^{*}$ Wilcoxon's test; †Student's $t$ test.

and therefore the $\mathrm{D}$-xyl/3-omG ratio remained unmodified; L-rh excretion was also unmodified during both disease phases with respect to controls. Lacl urinary excretion, however, underwent signifi-

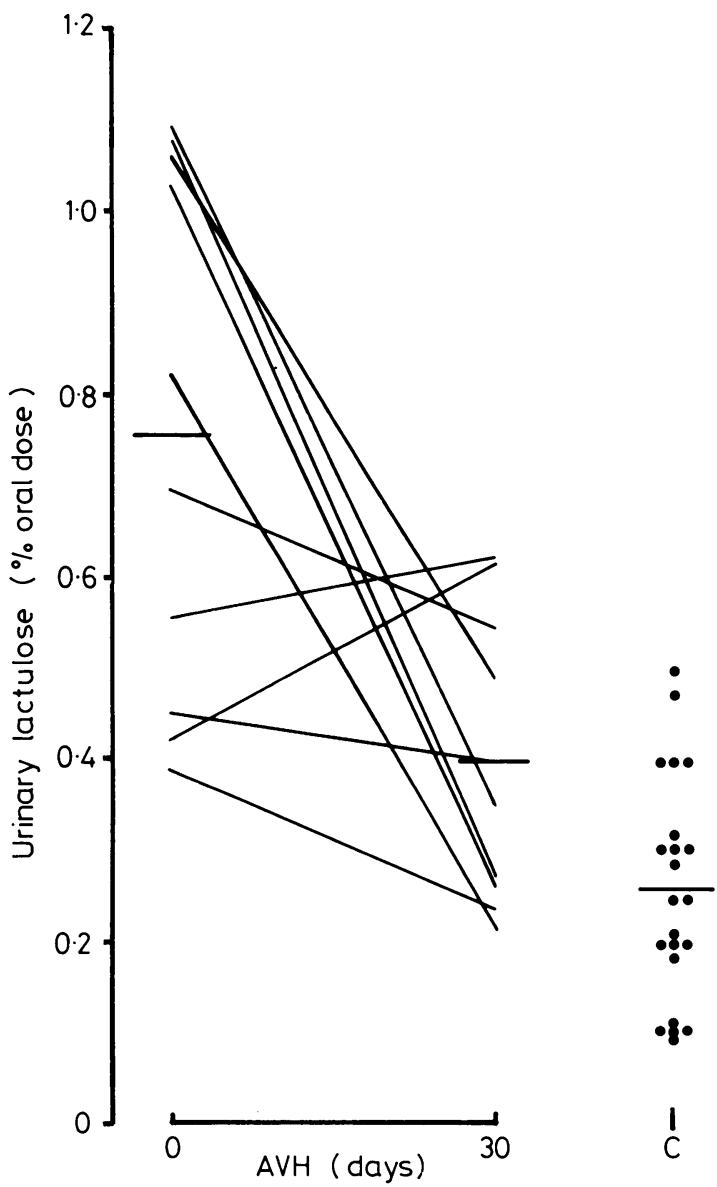

Fig. 3 Lactulose urinary recovery after oral load, in acute phase (0) and 30 days after (30) in patients with acute viral hepatitis and in controls $(C)$, with mean values. cant variations during hepatitis. In the acute phase it was three times greater, but had returned to near normal levels 30 days later. The Lacl/L-rh ratio followed the same course. Figure 3 shows this pattern of lactulose excretion in each patient in the two phases studied, and the control data.

\section{Discussion}

Our study revealed a functional gut derangement in acute AVH which was still evident during remission phase. We observed a marked increase in nonmediated intestinal permeation to Lacl at the onset of hepatitis, while the transmucosal transfer of small molecules like L-rh remained unaffected. Two distinct pathways are hypothesised for unmediated mucosal permeation, one consisting of small pores in the enterocyte cell membrane through which L-rh passes, and the other of larger channels related to the tight junctions and/or enterocyte extrusion zones. ${ }^{15}$ As Lacl is a probe molecule of the latter pathway our results indicate damage to these paracellular mechanisms. An analogous phenomenon has been described in allergic conditions such as atopic eczema, ${ }^{1 \times 19}$ in rheumatoid arthritis, ${ }^{211}$ and during cytotoxic therapy. ${ }^{21}$ The mechanisms involved in these pathological conditions are at present unknown. In the acute phase of hepatitis it is possible that a transient increase in portal pressure with a secondary alteration in cell metabolism is capable of influencing the paracellular pathways. An intestinal inflammation is less likely to occur because in typical acute gastroenteritis by rotavirus and adenovirus absorption of Lacl is increased and L-rh absorption is decreased, ${ }^{22}$ while our results showed a normal urinary recovery of L-rh. It is of interest that an abnormal increase in intestinal permeation to $\mathrm{Lacl}$ is also present in coeliac disease. ${ }^{23}$ This disease, however, is characterised by marked malabsorption of monosaccharides such as D-xyl and L-rh, as a consequence of reduced absorptive gut surface as a result of mucosal atrophy. ${ }^{23}$ In intestinal biopsies 
taken during AVH, only inconstant and non-specific minimal lesions have been observed, and there is no decrease in cell mass of the small intestine mucosa..$^{2+}$ The normal D-xyl and L-rh excretion in urine we observed in both acute and remission phases of hepatitis are in agreement with these findings; thus sugar malabsorption can be excluded. Approximately $50 \%$ of iv administered D-xyl is metabolised in man, mainly by the liver. ${ }^{25}$ The tendency for urinary xylose to increase in the presence of reduced hepatic metabolism of this sugar could obscure a possible decrease caused by coincident malabsorption. The unaltered excretion during the acute phase of hepatitis of L-rh, however, which is much less efficiently metabolised by the liver than is D-xyl, ${ }^{8}$ indicates that absorptive capacity remained normal.

The ratio of D-xyl to 3-omG in plasma allows a correct evaluation, according to the principle of differential absorption ${ }^{89}$ of the intestine's absorptive capacity, and is as reliable a test as xylose urinary excretion. In our study the $\mathrm{D}$-xyl/3-omG ratios in plasma and urine of hepatitic subjects did not differ from those of healthy controls, thus confirming the absence of malabsorption even in the acute phase of hepatitis.

The plasma curves of D-xyl and 3-omG, however, were abnormally low in the acute phase of $\mathrm{AVH}$, as were the plasma concentration/time area (PCTA) and the one hour sugar concentration. These findings bear a statistical correlation with hepatic cytonecrosis (Alanine aminotransaminase, ALT, $v$ D-xyl one hour $\mathrm{r}=-0.76, \mathrm{p}=0.01$; ALT $v$ 3-omG one hour $r=-0 \cdot 71, p=0 \cdot(022)$, and are the inverse of what one would expect in the case of reduced hepatic metabolisation (which, furthermore, is possible only for D-xyl). These data cannot be related to alterations in intestinal absorption, but may possibly be related to increased space distribution of the test sugars within the body because of the expansion of the extracellular space by fluid retention and/or increased diffusion into tissue cells.

An altered water sodium homeostasis with minor abnormalities in water excretion has been reported in acute hepatic disease not complicated by renal failure as shown by altered response to water loading. ${ }^{26} \mathrm{On}$ the other hand, increased permeability of blood capillaries, perhaps mediated by bile salt retention, ${ }^{27}$ has been observed in acute phase hepatitis by experiments with Evans blue diffusion. ${ }^{2 \times}$

In conclusion, our results rule out a monosaccharide malabsorption during acute AVH but disclose a marked increase in non mediated intestinal permeation to larger molecules like disaccharides. These data suggest a temporary alteration in large paracellular channels of the small intestine and appear difficult to explain by virus replication within intestinal cells. The low D-xyl and 3-omG concentrations in plasma could be interpreted by haemodilution and/or increased diffusion into tissue. The evaluation of the ratios of D-xyl to 3-omG in plasma and urine seem to express more satisfactorily, than other methods the small intestine's absorption capacity to monosaccharides.

This work was supported by a $60 \%$ grant from the Ministero della Pubblica Istruzione Italiana 1983. We wish to thank Mrs M Spears for her linguistic assistance, and Professor G Viggiani and Professor G Rotundo for technical assistance.

\section{References}

1 Stanley ML. Type A viral hepatitis. New developments in an old disease. N Engl J Med 1985; 313: 1059-67.

2 Bromberg K, Newhall DN, Peter G. Hepatitis A and meningoencephalitis. JAMA 1982; 247: 815 .

3 Sack DA, Rhoads M, Molla A, Molla AM, Wahed MA. Carbohydrate malabsorption in infants with rotavirus diarrhea. Am J Clin Nutr 1982; 36: 1112-8.

4 Nigro G, Cardi E, Donelli G, Tangucci F, Midulla M. Protracted carbohydrate malabsorption associated with rotavirus-astrovirus gastroenteritis in an infant without immunodeficiency. Ital J Gastroenterol 1985; 17: 38-9.

5 Conrad ME, Weintraub LR, Schwartz FD, Young AA. Viral hepatitis in Korea. In: Progress in liver disease. New York: Grune and Stratton, 1965; 2: 395.

6 Haney MR, Culank LS, Montgomery RD, Sammons HG. Evaluation of xylose absorption as measured in blood and urine - A one-hour blood xylose screening test in malabsorption. Gastroenterology 1978; 75: 393-400.

7 Fordtran JS, Clodi PH, Soergez KH. Ingelfinger FJ. Sugar absorption test, with special reference to 3omethyl-D-glucose and D-xylose. Ann Intern Med 1962; 57: 883-91.

8 Menzies IS. Medical importance of sugars in the alimentary tract. In: Gremby TH, Parker KJ, Lindley MG, eds. Developments in sweeteners. Vol. 2. London, New York: Applied Science Publisher. 1983.

9 Budillon G, Parrilli G, Pacella M, Cuomo R, Menzies IS. Investigation of intestine and liver function in cirrhosis using combined sugar oral loads. J Hepatol 1985; 1: 513-24.

10 Anonymous. Intestinal permeability. [Editorial]. Lancet 1985 ; ii: $256-7$.

11 Budillon G, Parrilli G, D’Agostino L, Capuano G, Mazzacca G, Menzies IS. Cholecystokinin and human intestinal permeability. Digestion 1980; 20: 68-72.

12 Budillon G, Parrilli G, Capuano G, Mazzacca G, Menzies IS. The cholecystokinin effect on human intestinal permeability - influence of chenodeoxycholic and ursodeoxycholic acid administration. Digestion 1982; 24: 274-80.

13 Chadwick VS, Philips SF, Hoffman AF. Measurement of intestinal permeability using low molecular weight polyethylene glycol. II. Application to normal and abnormal permeability states in man and animals. Gastroenterology 1977; 73: 247-51. 
14 Cook GC, Menzies IS. Intestinal absorption and unmediated permeation of sugars in post-infective tropical malabsorption (tropical sprue). Digestion 1986; 33: $109-16$.

15 Maxton DG, Bijarnason I, Reynolds AP, Catt SD, Peters TJ, Menzies IS. Lactulose ${ }^{51} \mathrm{Cr}$-labelled ethylenediaminetetra acetate, L-rhamnose and polyethyleneglycol 500 as probe markers for assessment in vivo of human intestinal permeability. Clin Sci 1986; 71: 71-80.

16 Menzies IS, Mount JN, Wheeler MJ. Quantitative estimation of clinically important monosaccharides in plasma by rapid thin layer chromatography. Ann Clin Biochem 1978; 15: 65-76.

17 Laker MF. Estimation of disaccharides in plasma and urine by gas liquid chromatography. J Chromatogr 1979; 163: 9-18.

18 Parrilli G, Ayala F, Lembo G, Cuomo R, Budillon G, Santoianni P. Abnormal intestinal permeability to lactulose in patients with atopic dermatitis. In: MacDonald DM, ed. Immunodermatology. London: Butterworths, 1984.

19 Jackson PG, Lessoff MH, Baker RVR, Ferret J, Macdonald DM. Intestinal permeability in patients with eczema and food allergy. Lancet 1981; i: 1285-6.

20 Bjarnason I, Alex SO, Jonathan Levi A, et al. Intestinal permeability and inflammation in rheumatoid arthritis: effect of non steroidal antiinflammatory drugs. Lancet 1984; ii: $1171-3$.

21 Parrilli G, Iaffaioli RV, Capuano G, Budillon G, Bianco AR. Changes in intestinal permeability to lactulose induced by cytotoxic chemotherapy. Cancer Treat Rep 1982; 66: 1435-6.

22 Noone C, Beach RC, Bull J, Menzies IS. Differential absorption of D-xylose and 3-omethyl-D-glucose in coeliac disease and acute gastroenteritis. [Abstract]. Gut 1982; 23: A291.

23 Menzies IS, Laker MF, Pounder R, et al. Abnormal intestinal permeability to sugars in villous atrophy. Lancet 1979; ii: 1107-9.

24 Astaldi G, Strosselli E, Poggi C. Stereomicroscopia della mucosa intestinale nell'epatite epidemica. Boll Soc Ital Biol Sperim 1963; 39: 250-4.

25 Fowler D, Cooke WT. Diagnostic significance of D-xylose excretion test. Gut 1960; 1: 67-70.

26 Papper S, Seifer HW, Saxon L. The diuretic response to administered water in patients with liver disease: Acute infectious hepatitis. Arch Intern Med 1959; 103: 746-9.

27 Coleman R, Lowe P, Billington D. Membrane lipid composition and susceptibility to bile salt damage. Biochim Biophys Acta 1980; 599: 294-300.

28 Ellegast $H$. Untersuchunghen zur frage der permeabilitatssorung bei lebereekrankungen. Acta Hepatol 1955; 3: 195-9. 